\title{
THE MYTH OF ALCESTIS AND ITS TREATMENT BY EFUA SUTHERLAND IN HER PLAY EDUFA
}

\author{
P J Conradie (University of Stellenbosch)
}

When looking at modern drama the development of African drama in English is one of the most interesting areas. While European dramatists frequently give the impression that they have nothing new to say and that they therefore concentrate on new methods of presentation, the African plays present all the issues confronting Africa today, including the clash of cultures. Especially fascinating in their plays is the fusion of European elements (frequently deplored but inescapable) and indigenous theatrical tradition.

Classical influences can also be discerned, although not always so clearly, as in J P Clark's Song of a goat. ${ }^{1}$ There are a few adaptations of Greek plays, ${ }^{2}$ and in this article I wish to discuss Edufa, a reinterpretation of Euripides' Alcestis by the Ghanaian dramatist Efua T Sutherland.

Euripides' play has given rise to much controversy. J R Wilson (1968:17) even states that it "has always been a critic's battlefield". According to the ancient hypothesis it occupied the fourth place in the tetralogy, the usual position of a satyr play, but it is too serious to be regarded as one, and there is no chorus of satyrs. On the other hand there are some comic scenes, especially the scene in which Heracles scolds the servant for not being friendly enough and exhorts him to enjoy life while it is possible. Furthermore the play has a happy ending. Many critics therefore describe it as a tragicomedy, e.g. Kitto (1950:312) and Barnes (1968:28). Conacher (1967:384) prefers to describe it as pro-satyric.

To understand Euripides' treatment better it would be useful to compare it with the original story. This is difficult as there is no original version extant. The Alcestis is rather peculiar in that it is based on a folk tale (some even describe it as a "fairy tale"), rather than a myth. There are certain fanciful elements in this folk tale which are different from the more realistic atmosphere of the ordinary heroic myth. Von Fritz (1962:299-300), relying on the work of Lesky, describes the original form of the story (which he calls a "legend") as follows: A young man or woman must die in the prime of his or her life. He asks Death to spare him, and Death agrees to do it if he can find somebody who is willing to die in his place. He asks friends and family, but no one is willing, until a mother, sister or loved one agrees. This could be the original form, but soon a happy ending is added, especially if it is a maiden who is prepared to sacrifice herself for her lover. She is rewarded by being restored to life, either because Death releases her voluntarily or is forced by somebody to

1 This play is not directly based on any Greek tragedy, but many critics discover Greek influences, cf. Costello 1981:66. The title also reminds us of the literal meaning of $\tau \rho \alpha \gamma \omega \delta i \alpha$.

2 The Bacchae of Euripides by Wole Soyinka, The gods are not to blame by Ola Rotimi and Edufa by Sutherland. 
release her. This development shows a resemblance to another folk tale about a hero who struggles with Death, forcing him to release his victim. Among the Greeks, as von Fritz remarks, this tale became more individualized when the young man was called King Admetus and the young woman his wife Alcestis.

The original tale can be regarded as an answer to the question who has the most love-mother, sister or loved one. The right of the young man to accept the sacrifice of the young woman is not questioned. When Euripides dramatizes this story, however, the question comes to the fore whether Admetus is justified in accepting his wife's offer to die in his stead. This is done in a very subtle way. In the prologue Apollo just states the facts without any comment. Through his intercession Admetus was granted escape from imminent death if he could find another to die in his place. Admetus asked all the members of his family, but no one was willing except his wife. In the following scenes, however, there are hints of criticism of Admetus' conduct. The servant girl who describes how Alcestis takes leave of her house and marriage bed, concludes the description with these words: "Such are the sorrows in the house of Admetus. If he had died himself-well, he would have died. Instead, he possesses a memory that will torment him as long as he lives" (196-198, Vellacott translation).

In the next scene in which Alcestis bids farewell to her husband and children, Admetus' extravagant expressions of grief inevitably forces the spectator to ask who is really responsible for the death of Alcestis. This is especially noticeable when he pleads with her not to leave him-and the Greek word $\pi \rho 0 \delta o v i \nu \alpha \iota$ is very strong, really meaning "to betray", as Wesley Smith (1968:40) emphasizes in his article "The ironic structure in Alcestis". And Admetus' intention of putting a statue of Alcestis in his bed is so fantastic that one begins to doubt his sincerity. Some critics also detect a note of criticism in Alcestis' last speech in which she emphasizes her great sacrifice and orders her husband not to marry again. But A M Dale (1954:xxxix) warns against reading too much characterization in this scene and draws attention to the rhetorical element: "Alcestis has to win her husband's promise never to marry again; her strongest arguments are the magnitude of her own sacrifice and the emotion aroused at the thought of the motherless children and her own death. So like a skilful pleader she makes the most of things...."

There is no doubt, however, that in the scene in which he quarrels with his father Pheres, Admetus' conduct in accepting his wife's sacrifice is severely criticized, even if the criticism is rather one-sided coming from an old man who refused to sacrifice his own life. Admetus blames his father for refusing to die in his place, although he is old and has had a happy life, but Pheres is not ashamed of his love of life and very justly finds the same desire in Admetus. Although the spectator will not admire Pheres' attitude, he will be very disturbed by the fact that Admetus does not seem to be aware of his own self-centredness and the irony of the situation.

Finally, in the scene after Admetus has returned from the grave, he seems to realize what he has lost by the death of his wife- $\alpha \rho \tau \iota \mu \alpha \nu \theta \alpha \dot{\alpha} \omega(940)$ "Too late I know". Life is not worth living without his wife, and in addition his enemies will whisper: "There goes the man who did not dare to die, who has bought a coward's 
life with his own wife's death" (955-959, Vellacott translation). Again the critics differ about the question how deep this repentance goes, but there is no doubt about the fact that Admetus has now realized the consequences of his matter of fact acceptance of his wife's sacrifice.

Another peculiar element in Euripides' play is the role of Heracles. As mentioned previously, the later elaboration of the folk tale led to the rescue of Alcestis from death. This frequently takes the form of a struggle in which Death is conquered and forced to release his victim. Euripides chose Heracles for this purpose. It is not certain whether this was Euripides' innovation; many critics are inclined to think so, but it cannot be proved. In any case, this is not very important, for the main point is the way in which he is portrayed by the dramatist. In Greek myth Heracles is a heroic character, but he also has certain comic traits, like his love of women and good food.The latter characteristic is stressed in this play when Heracles, ignorant of the death of Alcestis, boisterously enjoys his food and drink and scolds the servant. This scene has strong comic overtones. Another strange scene is that in which Heracles returns with the veiled Alcestis and pretends that she is a young woman whom Admetus is to keep in his house while Heracles is away. Admetus at first refuses, but Heracles banteringly insists and finally Admetus agrees to his request. Again the question arises: Is this a test of Admetus' fidelity and what conclusions are to be drawn from his compliance? Is he no longer faithful to his promise, or is it only his decency and hospitality which prevails?

After Euripides' treatment of this myth, no subsequent dramatist could ignore the questions it raised. Von Fritz (1962:263ff.) has written a long article on later adaptations of this story and its implications for the interpretation of Euripides. I mention only a few attempts to explain (and justify) Admetus' behaviour which throw an interesting light on Sutherland's version.

One possible explanation of how Admetus could accept Alcestis' offer, is that he knew nothing of her intentions beforehand and once she had vowed to die in his place, her promise was irrevocable. This was the solution of Wieland, a contemporary of Goethe, in his lyrical drama (Singspiel) Alceste (Wieland 1967:75107). When Admetus is informed of her decision, he can do nothing to save her. Therefore he can implore her not to leave him without causing the spectator to doubt his sincerity. Hofmannsthal has a more subtle version of the same idea. When Admetus heard of the possibility that some one might die in his place, "he trembled between shame and fear of death and asked, but scarcely had he asked the question when he repented, and he wished he were dead. His old parents heard him but trembled and were silent". Then Alcestis came forward and offered to die in his place. Immediately her wish was granted, and when Admetus "desperately frightened, threw his arms around her, he embraced someone who was already dedicated to death" (Hofmannsthal 1953:10; my translation).

Goethe was irritated by the superlative goodness of all the characters in Wieland's play and in reaction he wrote a farce Götter, Helden und Wieland in which Admetus without any shame defends his desire to go on living: 
A young and completely satisfied sovereign, who received from his father empire and inheritance and flocks and possessions, and enjoyed it with pleasure and needed nothing else than people who could enjoy it with him, and of course also found them, and never had enough of giving and loved everyone ... and made friends of gods and men ... why should he not wish to live forever? (Goethe 1953:209; my translation).

Against this background I wish to discuss Efua Sutherland's adaptation of this myth. She transposed it to an African setting, presumably a town in Ghana. Admetus becomes Edufa, a wealthy man of authority in the town; his wife is Ampoma and his father Kamkam; Heracles becomes his friend Senchi, and the usual nurse of Greek tragedy becomes Seguwa, described as a "matronly member of the household". (In Euripides' play there is no Nurse, only a servant girl who describes Alcestis' leave taking.)

Since Sutherland's play is constructed differently, it will be useful to give a short résumé of the plot. In the prologue Abena, the sister of Edufa, sits in the courtyard, watching dew falling in a black pot. Together with water from the stream it is destined for a ceremony for which she does not know the reason. She only knows that Ampoma is ill and that Edufa has shut the house to keep visitors out. In the first scene Edufa and Seguwa perform a ceremony, pouring the water over herbs in the bathroom and burning incense. Seguwa knows the reason for performing this ceremony but is sworn to secrecy. A long dialogue between Ampoma and Edufa follows. She feels that she is dying and is really taking leave of him and the children, but he tries to encourage her. Seguwa is indignant at the whole situation. Finally, in a quarrel between Edufa and his father Kamkam, the secret is revealed. Four years previously Edufa went to a diviner who saw death "hanging" over his life, but also said that he could avert the danger if someone else swore over a powerful charm to die in his place. Pretending that it was a joke, Edufa asked who loved him well enough to die for him. He thought to trap his father but instead Ampoma spoke the fatal words and refused to retract them, even though he pleaded with her. Since that time she has lived under a cloud. Edufa tries to deny everything and refuses to accept his father's advice. In Act Two the chorus is introduced. It consists of women who go through the town performing a rite "to beat envious evil out of the house"; they sing a song which has already been heard in the distance during the previous act: "We the orphans cry / our mother's dead." Edufa welcomes them, but tries to persuade them to leave the house as soon as possible. When his friend Senchi arrives however, he is forced by his sense of hospitality to invite the women to a party that same evening. He is encouraged to do this by the news that Ampoma is feeling much better. The act ends with the arrival of the idiot Sam who has brought back a box of goods from the diviner, including a charm which has to be burnt. Edufa is now confident that the danger to Ampoma can be averted.

The third act consists mainly of a description of the party which Senchi and the women enjoy greatly-eating, drinking, dancing and singing. Edufa expresses his love for her and gives her flowers. Ampoma, when she appears later, also shows her 
love for him by giving him waist beads. But it is clear that she is not well and there are ominous signs. In the end she dies and Edufa, beside himself, vows to rescue her from death, but it is clear that he is hallucinating. Senchi can do nothing: "I have ended up blank again" (Sutherland 1987:154).

If we look at the play as a whole we see that, while the resemblances to Euripides' play are clear, there are significant differences. The most important, of course, is that Ampoma dies and is not rescued from death. In this way the emphasis is completely different, for the play is focussed on the death of Ampoma. The audience is waiting in suspense for it, but it does not take place until the end of the play. As Ogunba (1971:97) says: "The whole of the play turns out to be a great but hopeless effort to retrieve the position and save the wife." Thus the play ends as a tragedy, not as a tragicomedy. Furthermore, there are in fact only two scenes closely resembling Euripides. In the scene in which Ampoma gives her last instructions to Edufa, there are many echoes of Euripides. The quarrel between Edufa and Kamkam differs in detail from that between Admetus and his father but has the same general meaning. In addition, Edufa's last words are practically a translation of those of Heracles when he goes to rescue Alcestis:

Where is my leopard skin. I'll teach Death to steal my wives. Death, I will lie closely at the grave again, and when you come gloating with your spoil, I'll grab you, unlock her from your grip and bring her safely home to my bed (Sutherland 1987:153).

Here, of course, these words are ironic.

The most interesting aspect of the play is the characterisation of Edufa. Without doubt he is the main character of the play which is justly named after him. He is a very complex character. Strangely enough, some critics do not appreciate this. Graham-White (1986:813) describes him as "just a selfish member of the new class of privileged nouveaux riches". Saint-Andre Utudjian (1992:189) says: "However, some audiences might feel uneasy with such an obnoxious hero, a man of two worlds, at home in neither."

Edufa is very wealthy and an important person in the town; everyone greets him respectfully. It is important to note that he intensely enjoys his wealth and the honour given to him, and he does not want to lose it. As he says to Senchi:

Ask the town. They know who Edufa is and what he is worth. They can count you out my value in the homes that eat because I live. They rise in deference from their chairs when they say my name. If that is not something, what is? And can a man allow himself to lose grip on that? And there's the strain that rips you apart! The pain of holding on to what you have (Sutherland 1987:132).

In these words his materialism is clear, but also his doubts about his own values, which he is sincere enough to admit. This materialism seems also to be the cause of his estrangement from his father. Kamkam says: 
I want the courage that makes responsible men. I want truthfulness. Decency. Feeling for your fellow men.... Have you got them to give? I fear not, since you have sold such treasures to buy yourself the importance that fools admire (Sutherland 1987:97).

I am not quite sure, however, that these words justify Ogunba's conclusion (1971:47): "He also acquired his riches by similar dubious means which warrant his early death."

As in Euripides' play Edufa is known for his hospitality: "the house of the open gate", one of the women of the chorus calls it. Since Ampoma's illness he has shut the gate, but the arrival of Senchi while the women of the chorus are there, practically forces him to give a party, which forms an ironic background to Ampoma's death. In this case his hospitality does not rescue him.

The most intriguing aspect of Edufa's character is the ambivalence of his beliefs. He pretends to be an emancipated man who rejects traditional beliefs. As frequently happens, he then cannot find a religion or philosophy that satisfies him. As Senchi says:

Say, have you changed your religion again. What are you practising now? Catholicism, spiritualism, neo-theosophy or what? Last time I passed through here, you were an intellectual atheist, or something in that category (Sutherland 1987:122).

At the same time he has not really freed himself from superstition, and still believes in diviners and the power of witchcraft. Therefore he consults the diviner and acts on his advice. When his plan with the charm miscarries, he desperately tries to counter the effect with other rites. He is also superstitious about the owl of the idiot Sam and terrified when Ampoma stumbles on the step. But he does not accept his father's advice to confess openly and ask for everybody's prayers.

The explanation of how Edufa mistakenly persuaded Ampoma to die in his place and when he later regretted it, desperately tried to cancel it, is very ingenious. It resembles Hofmannsthal's version. Some critics show their appreciation for this. Saint-Andre Utudjian (1992:189) says: "The themes of witchcraft versus modern rationalism, materialism versus traditional values, generational conflict ... and of a wife's questioning of her husband's behaviour, are subjects of concern to educated Ghanaians caught between two cultures." And Ogunba (1971:980), in spite of serious objections, says the play has "a seriousness that strikes at the fundamental problem of a modern Ghanaian seeking shelter under traditional sanctions whose potency has been reduced by modernism".

Lewis Nkosi (1981:179-180) has a serious objection from a strictly ideological point of view. He speaks of the "failure to resolve what is in its fullest implications, an ideological conflict between a modern critical spirit and a belief in traditional systems of religious faith and magic", and adds, "All in all, it is the enforced marriage between the supernatural and the realistic mode which undoes Efua Sutherland's play". I do not agree with this point of view. Superstition and a belief in the supernatural is widespread even among so-called enlightened and rational 
persons; a dramatist may make use of this ambivalence even in a realistic play, and leave it to the spectator to draw his own conclusions.

Ampoma is portrayed as a loving wife who is prepared to sacrifice everything: until the end she shows her love for her husband who has in fact cheated her. She does not show much individuality, and although Saint-Andre Utudjian's description (1992:89) of her as "the heroine, a whining woman, recklessly leaving two orphans behind her and dying for the sake of a coward", is too harsh, it is true that she does not make a very strong impression. Ogunba (1971:98) describes her as a good and doting wife who becomes a victim of the scheming and crude materialism of her husband". Nkosi (1981:179), of course, protests against the failure "to make explicit what remains in the text an implicit criticism of a male dominated society, a dimly perceived wrong done to women".

The portrayal of Senchi is interesting. He is supposed to be the African equivalent of Heracles, but he does not perform the latter's main task, namely of rescuing the hero's wife. In the end he is helpless to do anything. Graham-White (1986:814) even calls him "a seedy intellectual". This is unfair, but it is worthwhile asking what his real function in the play is. As in Euripides' play he illustrates Edufa's hospitality. Even though he is worried about his wife's health, Edufa welcomes Senchi heartily and even organises a party for him. Senchi thoroughly enjoys this party and the company of the women of the chorus; they dance in a procession round the room. Thus he shows that he has the same joie de vivre as Heracles, but perhaps this part of the play is too drawn out to be really functional.

The main function of Senchi, in my opinion, is to serve as a contrast to Edufa's attitude towards life. This is especially evident in the first scene of the third act where Senchi talks more seriously than usual with his host. Edufa tells him that he admires him, although he cannot show a balance in the bank, but asks him whether he does not think that it is important to have solidity. Senchi does not really answer his question, but when he talks about his suit, his attitude towards life becomes clearer:

My own suit may be shabby, but its shabbiness is of my own making. I understand it. It is a guide to self-evaluation. When I stand in it, I know where I stand and why. And that, strangely, means to me dignity and security (Sutherland 1987:133).

M L Costello (1981) discusses Senchi's portrayal very extensively, and even calls him "a non-face"; more to the point he states "the mores of Ghanaian society are expressed in his exchanges with the chorus and in his story telling. These facets of his dramatic persona evince a greater critical/intellectual involvement with his fellow human beings than does Heracles' special power over destiny" (1981:35). Edufa's father Kamkam is a much more dignified character than the father of Admetus. He cannot be accused of cowardice because his son failed to trick him in sacrificing his life; therefore he is justified in reprimanding his son and advising him to confess everything. This scene is placed much earlier than in Euripides' play and has an important function in revealing the circumstances in which Ampoma vowed to die in 
her husband's place-quite different from the straightforward way in which Alcestis was asked. Graham-White (1986:814) says that he is "endowed with impressive dignity, wisdom and insight".

Sutherland makes an interesting use of the Chorus. This is an element of Greek tragedy which is usually omitted by modern dramatists, but African dramatists seem to adapt to it more naturally. The chorus of young women in Edufa differs greatly from Euripides' chorus of old men, but they also represent the feelings of the ordinary people of the town. They share a greater part of the action since they are guests at Edufa's party. As Costello (1981:34) remarks: "By giving Edufa not one but many guests to entertain, Sutherland has enlarged the social situation created for Admetus by the arrival of Heracles". Ogunba $(1971: 88)$ even states that the chorus gives dignity to the play: "This chorus helps to keep Edufa from being a mere figure of fun and imbues the play with seriousness".

The dramatist makes good use of the fact that the women of the chorus originally take part in an annual ceremony in which funeral songs are sung to expel evil from the town. The irony of their song, "Ei! Ei-Ei! / We the orphans cry / Our mother's dead", is very apparent under the circumstances, though perhaps it is a bit over-emphasized; Graham-White (1986:814) speaks of "heavy irony". There is a contrast between the solemn nature of the ceremony which they perform and the gaiety with which they welcome any form of entertainment. Sutherland also uses both Senchi and the chorus to introduce music, song and dance during the party in the third act. Senchi's song in honour of Ampoma is very effective: "She's wonderful! / She's wonderful! / O, Mother / She's wonderful" (Sutherland 1987:135). For the audience who know the truth, it has a special meaning, which is emphasized when it is repeated after her death.

A very interesting aspect of the play is the way in which the plot is transposed from Greece to Africa, a process which frequently poses difficult problems for the dramatist. In this case, perhaps, it is easier because the plot derives from a folk tale rather than a myth, and therefore is of more general human interest, and not so clearly bound up with Greek culture. E J Asgill (1980:176) even describes it as "a popular African mystical belief ... that a man could postpone his own death by the substitution of another's life" but he does not give any evidence for this. Edufa is not quite a king, but is an important person in the town, and everybody regards him with great respect, just like a king. Apollo, of course, does not appear at all and his place is taken by the diviner who foretells Edufa's death but also mentions the possibility that someone may die in his place, a change which fits naturally an African context. Another addition is the charm on which the substitute has to swear that he or she is prepared to die in Edufa's place. Costello (1981:500) describes it as a "deft cultural adjustment". Sutherland has not only found African equivalents for the Greek plot, but has used them to further her own plot.

An important theme in the play is the idea that destiny-that is, Ampoma's death which is inevitable as soon as she has sworn her oath-may be averted by the use of certain rituals. This idea plays an important part in the play, which starts with Edufa's sister Abena staying awake to collect dew in a black water pot. The dew, 
together with water from a stream, is to be poured over herbs in the bathroom for Edufa and his wife to bath in. At the same time incense is to be burned. The idiot Sam is sent to the diviner, and brings back the fateful charm for Edufa to burn. In this way Edufa hopes to save his wife. It is remarkable that Kamkam also cherishes the hope that Ampoma's life may be saved, but his remedy is somewhat different:

Confess and denounce your wrong. Bring out that evil charm. And before Ampoma and all of us whose souls are corporate in this household, denounce it. Burn it. The harm may not be irrevocably done if we raise the prayer of our souls together (Sutherland 1987:112).

Another addition is the atmosphere of foreboding in the play. In Euripides' play it is certain that Alcestis will die, but in Sutherland's play the hope is kept alive that she may be saved; in fact only a few characters know about the danger threatening her. From time to time ominous signs of the impending catastrophe appear: Abena, waiting for the dew to fall, hears Ampoma calling in a dream and sees a misty figure on an anthill. The idiot Sam arrives with an owl which frightens both Seguwa and Edufa himself, and, most ominous of all, Ampoma falls three times, the last time on a painted sign of the sun. I have already mentioned the song of the chorus which they sing to drive evil away. Their answer when Edufa asks the reason for their coming are more ominous than they realise: "to purge your house also in the same old manner, for calamity is for all mankind and none is free from woe" (Sutherland 1987:119).

Thus it can be said that the transposition of the play to Africa has, on the whole, been successfully accomplished. But critics are always quick to notice discrepancies. According to Saint-Andre Utudjian (1992:189), "The elements borrowed from Greek life and customs-like Ampoma's prayer to her husband that he should not remarry after her death and Edufa's offering a bunch of roses to his dying wife-are particularly out of place in an African setting". The bunch of roses, of course, does not come from Euripides' play! The request not to remarry, however, poses a bigger problem and perhaps here the criticisms are justified.

In conclusion it may be said that Sutherland has taken an idea from the Greek tragedy and developed it in her own way to produce a very impressive play. Costello puts it very well (1981:50):

Sutherland is plumbing the depths of the literal story for its symbolic possibilities in terms of a traditional African idea: or, to put it in another way, she is both naturalising and Africanizing the original folk mystery.... Again we get a brief insight into one of those analogues (linguistic, literary, moral) which explain the African writer's sense of affinities with the tribal/oral parallels in ancient Greek culture.

\section{BIBLIOGRAPHY}

Asgill, E J 1980. African adaptations of Greek tragedies. African literature today 11:175-189. 
Barnes, H E 1968. Greek tragicomedy. In Wilson 1968.

Conacher, D J 1967. Euripidean tragedy. University of Toronto Press.

Costello, M L 1981. Greek drama and the African world. PhD dissertation, University of Southern California.

Dale, A M 1954. Euripides, Alcestis. Oxford: Clarendon Press.

Goethe, J W 1953. Götter, Helden und Wieland. In Goethe's Werke. Band 4. Hamburg: Wegner.

Graham-White, A 1986. Ghana: Drama. In Gerard, A S (ed), European writing in Sub-Saharan Africa. Vol. 2, 810-820.

Hofmannsthal, $\mathrm{H}$ von 1953. Alkestis. In Hofmannsthal, $\mathrm{H}$ von. Werke. Band 3. Frankfurt: Fischer.

Kitto, H D F 1950. Greek tragedy. 2d ed. London: Methuen.

Nkosi, L 1981. Tasks and masks. Harlow: Longman.

Ogunba, O 1971. Modern drama in West Africa. In Heywood, C (ed), Perspectives on African literature. London: Heinemann.

Saint-Andre Utudjian, E 1992. Commonwealth drama since 1960: Ghana and Nigeria. In King, B (ed), Post-colonial English drama. New York: St. Martin's Press.

Smith, W D 1968. The ironic structure in Alcestis. In Wilson 1968.

Sutherland, E T 1987. The marriage of Anansewa and Edufa. Harlow: Longman.

Vellacott, P (trans) 1953. Euripides: Three plays. Harmondsworth: Penguin.

Von Fritz, K 1962. Antike und moderne Tragödie. Berlyn: De Gruyter.

Wieland, C M 1967. Alceste. In Wieland, C M, Werke. Band 3. München: Carl Hauser.

Wilson, J R 1968. Twentieth-century interpretations of Euripides' Alcestis. Englewood Cliffs: Prentice-Hall. 